
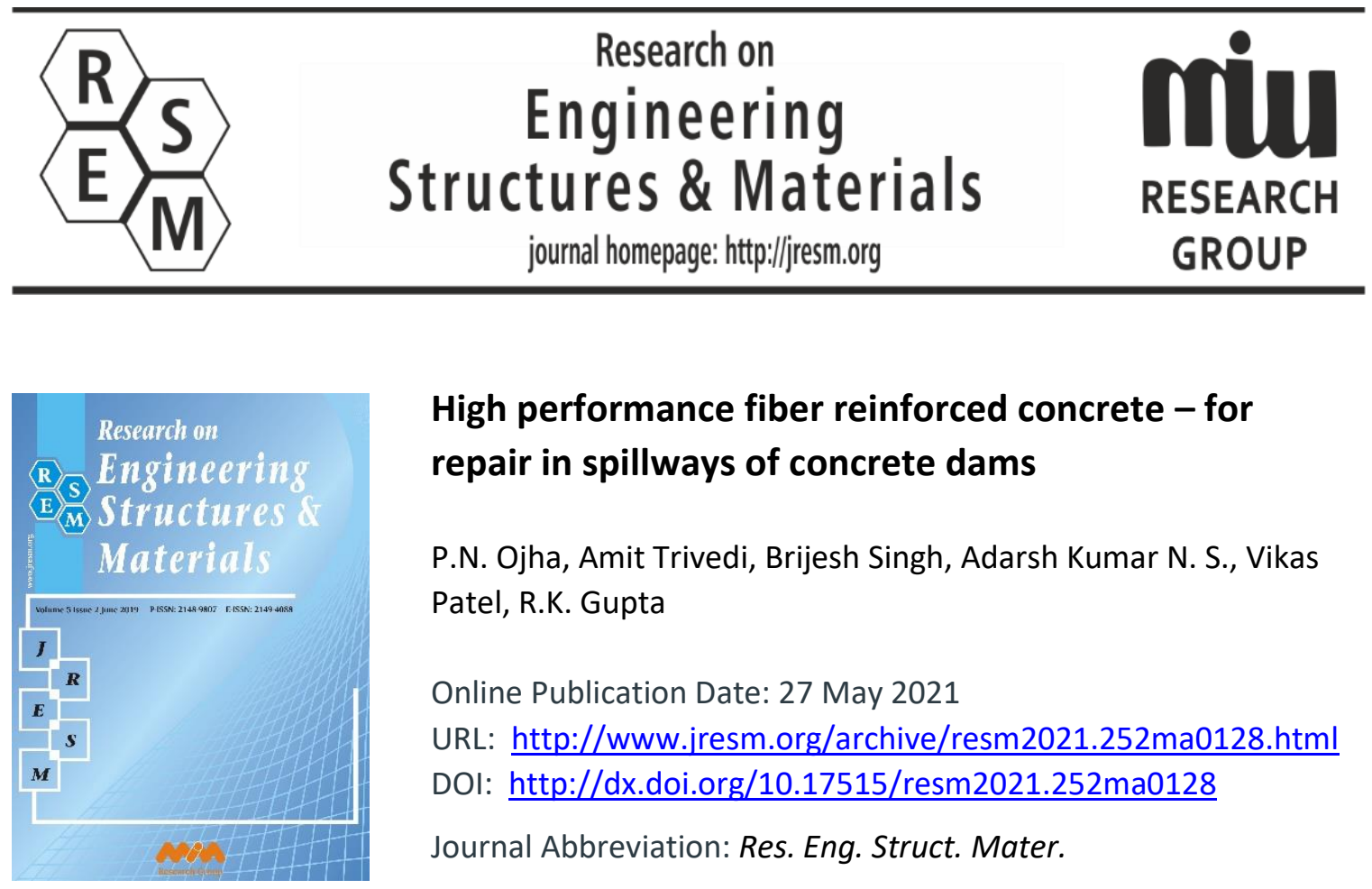

\title{
High performance fiber reinforced concrete - for repair in spillways of concrete dams
}

\author{
P.N. Ojha, Amit Trivedi, Brijesh Singh, Adarsh Kumar N. S., Vikas \\ Patel, R.K. Gupta
}

Online Publication Date: 27 May 2021

URL: http://www.jresm.org/archive/resm2021.252ma0128.html

DOI: http://dx.doi.org/10.17515/resm2021.252ma0128

Journal Abbreviation: Res. Eng. Struct. Mater.

\section{To cite this article}

Ojha P.N., Trivedi A., Singh B., Kumar N. S. A., Patel V., Gupta R. K. High performance fiber reinforced concrete - for repair in spillways of concrete dams. Res. Eng. Struct. Mater., 2021; 7(4): 505-522.

\section{Disclaimer}

All the opinions and statements expressed in the papers are on the responsibility of author(s) and are not to be regarded as those of the journal of Research on Engineering Structures and Materials (RESM) organization or related parties. The publishers make no warranty, explicit or implied, or make any representation with respect to the contents of any article will be complete or accurate or up to date. The accuracy of any instructions, equations, or other information should be independently verified. The publisher and related parties shall not be liable for any loss, actions, claims, proceedings, demand or costs or damages whatsoever or howsoever caused arising directly or indirectly in connection with use of the information given in the journal or related means.

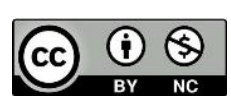

Published articles are freely available to users under the terms of Creative Commons Attribution - NonCommercial 4.0 International Public License, as currently displayed at here (the "CC BY - NC"). 


\title{
Research on Engineering Structures \& Materials
}

journal homepage: http://jresm.org

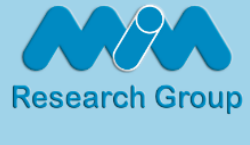

Research Article

\section{High performance fiber reinforced concrete - for repair in spillways of concrete dams}

\author{
P.N. Ojha ${ }^{1, \mathrm{a}}$, Amit Trivedi1,b, Brijesh Singh ${ }^{1, \mathrm{c}}$, Adarsh Kumar N. S. ${ }^{1, \mathrm{~d}}$, Vikas Patel ${ }^{* 1, \mathrm{e}}$, \\ R.K. Gupta ${ }^{2, \mathrm{f}}$
}

${ }^{1}$ National Council for Cement and Building Materials, India

${ }^{2}$ NHPC Limited, India

\begin{tabular}{|c|c|}
\hline Article Info & Abstract \\
\hline $\begin{array}{l}\text { Article history: } \\
\text { Received } 28 \text { Jan } 2021 \\
\text { Revised } 16 \text { May } 2021 \\
\text { Accepted } 26 \text { May } 2021 \\
\end{array}$ & $\begin{array}{l}\text { Hydraulic structures like spillways, glacis, etc. undergoes abrasion-erosion due } \\
\text { to impact \& cavitation losses due to the flowing water action. To overcome the } \\
\text { deterioration of the concrete in such structures, addition of fibers to the concrete } \\
\text { can be viable solution as it is known to increase the structural integrity of the } \\
\text { concrete. A comparative study of various engineering characteristics using high }\end{array}$ \\
\hline $\begin{array}{l}\text { Keywords: } \\
\text { Fiber reinforced } \\
\text { concrete; } \\
\text { High performance } \\
\text { concrete; } \\
\text { Polypropylene fibers; } \\
\text { Spillways; } \\
\text { Concrete dams; }\end{array}$ & $\begin{array}{l}\text { has been carried out. Water/binder ratio of } 0.23 \text { has been kept constant for the } \\
\text { study. Dosage for steel fibers is kept as } 1,1.25 \text { and } 1.5 \% \text { by volume while for } \\
\text { polypropylene fibers were kept as } 1,2 \& 3 \mathrm{~kg} / \mathrm{m} 3 \text {. Engineering properties such } \\
\text { compressive strength, flexural strength, toughness, energy absorption, splitting } \\
\text { tensile strength, drying shrinkage, abrasion resistance, and water and air } \\
\text { permeability of high-performance concrete with \& without fibers in its fresh \& } \\
\text { hardened state are investigated in this paper. Based on the study, the steel fibers } \\
\text { with } 1.5 \% \text { dosage are found to be more effective in countering the abrasive and } \\
\text { repetitive loading which can be more effective in the repairs of spillways and } \\
\text { glacis of concrete dams. }\end{array}$ \\
\hline
\end{tabular}

Abrasion resistance

(C) 2021 MIM Research Group. All rights reserved.

\section{Introduction}

The abrasive action of waterborne solid particles such as boulders, debris etc. at high velocity is one of the major issues while design of the hydraulic structures like spillways, glacis etc. Therefore, it is desired to develop a high-performance concrete that can provide high abrasion-erosion \& cavitation resistance to sustain the high velocities \& impact containing silt and rolling boulders over the hydraulic structures. This in turn will also reduce operation and maintenance cost of the structures.

Liu \& Donald [1], Holland [2], Papenfus [3], Galvao, Portella \& Kormann [4] reported that abrasion erosion resistance of concrete increases with the increase in compressive strength. Liu \& Donald [1], Holland [2], Wu, Yen, Liu \& Hsu [5] reported water-to-cement ratio as an important factor and recommended to adopt the lowest practical water-cement ratio where abrasion-erosion is of major concern. Liu \& Donald [1], Holland [2], Kryzanowski, Mikos, Sustersic \& Planinc [6], Papenfus [3] investigated the abrasion erosion resistance using different types of coarse aggregates in concrete composite. The test results indicate that abrasion erosion resistance of concrete increases with the increase in the hardness of coarse aggregates when the water to-cement ratio and compressive strength are kept constants and concluded that the hardest available

\footnotetext{
*Corresponding author: vikas.patel299@gmail.com

a orcid.org/0000-0003-1754-4488; b orcid.org/0000-0002-2594-4679; c orcid.org/0000-0002-6512-1968;

d orcid.org/0000-0001-6125-4408; e orcid.org/0000-0002-2251-3849; f orcid.org/0000-0001-5021-3774 DOI: http://dx.doi.org/10.17515/resm2021.252ma0128

Res. Eng. Struct. Mat. Vol. 7 Iss. 4 (2021) 505-522 
aggregate should be used in new construction or repair of stilling basins or other hydraulic structures.

Holland [2] \& Papenfus [3], ACI 546.R [7] \& ACI 210.R [8] Committee reported that the concrete containing silica fume \& high range water reducing agent has better abrasion erosion resistance where hard aggregate was not available to develop very high strength concrete. Liu \& Donald [1], Holland [2], Papenfus [3], Galvao, Portella \& Kormann [4] reported that impregnation of Polymer \& Epoxy in concrete mix and Surface treatment with coatings like polyurethane improves abrasion-erosion resistance. Kryzanowski, Mikos, Sustersic \& Planinc [6], Galvao, Portella \& Kormann [4] investigated and found that the introduction of granular rubber/waste rubber with complementary polymer binder increases the abrasion-erosion resistance of concrete.

It is important to note the difference between erosion caused by impact forces such as cavitation caused by rocks and debris impacting at high velocity and type of erosion that occurs due to wearing action of low velocity particles. Contradictory data are available regarding the performance of SFRC on abrasion-erosion \& cavitation. Liu \& Donald [1], Holland [2] reported that FRC is less resistant to abrasion-erosion due to smaller particles at lower velocities when compared with concrete without fibers. This is because of the adjustments in the mixture proportions to accommodate the fiber requirement which reduces coarse aggregate content and increases the paste content. As per the ACI 544.4R [9] committee report both laboratory tests and full-scale field trials have shown Steel Fiber Reinforced Concrete (SFRC) has high resistance to cavitation's forces resulting from highvelocity water flow and the damage caused by the impact of large waterborne debris at high velocity.

Lin \& Cheng [10] studied the performance of inclusion of steel fibers and silica fume in the concrete composite and found that abrasion resistance of concrete is improved by $8-15 \%$. Hu \& Yin [11] studied the impact angle of abrasion and found that steel fibers improve erosion resistance at low impact angle ( $\varnothing=15$ degree). Stig Ostfjord [12], Papenfus [3] \& ACI 544.1R [13] reported that adding fibers in concrete can enhance toughness, moment capacity, tensile strength, stiffness and brittleness of concrete. Stig Ostfjord [12], ACI 544.1R [13], Shah \& Jenq [14], Gopalaratnam \& Shah [15], Kamal, Kassimi \& Ghoddousi [16] concluded that steel fibers can absorb the deformation energy of concrete and reduce the risk of cracking. While designing the abrasion resistant concrete, abrasion resistance alone should not be emphasized rather the abrasion resistance of concrete should be assessed based on different parameters that defines the mechanical properties of concrete. Mechanical properties such as compressive strength, tensile strength, aggregate strength, modulus of elasticity, toughness, impact strength, chemical Admixtures, surface polishing $\&$ coatings, curing and other additives (Silica Fume and fibers) must be assessed in order to assess the abrasion-erosion \& cavitation resistance [17].

Satish Sharma et.al. [18-19] concluded that the addition of 5\% silica fume shows significant improvement in compressive strength, flexural strength, static modulus of elasticity, split tensile strength, drying shrinkage and water permeability. Inclusion of steel fiber increases the abrasion resistance of concrete. The inclusion of silica fume might have enhanced the bond between steel fibers and paste. Bond strength between fibers and paste is another important factor, associated with abrasion resistance. Based on the results, the recycled concrete and recycled fiber concrete with the proposed mix design have a high compressive strength, and due to relatively high porosity of the recycled aggregate concrete, its density has decreased by $2.48 \%$ and its water absorption increased by $54 \%$ compared to the natural concrete [20].

The exceptional characteristics of high-performance fiber reinforced concrete in comparison to conventional concrete make it a very good choice for long-span bridges and 
high-rise buildings (21) and in recent many attempts have been made to characterize the behavior of fiber-reinforced concrete (FRC) both experimentally and numerically in various conditions $(22,23,24,25)$. Various types of fibers such as natural and polymeric, e.g. polypropylene (PP) may be used to enhance the performance of concrete for different applications. The enhancement of different types of fibers on the flexural strengths and toughness is mainly attributed to the fiber crack-bridging and load-carrying capacities wherein the fibers alter the failure pattern and results in the ductile failure of concrete. Specimens with hooked-end fibers show the best flexural performance. An increase in volume fractions of both steel and polypropylene fibers leads to an increase in the compressive, splitting tensile and flexural strengths of concrete $(26,27)$. The post-peak ductility of concrete is improved and the strength degradation is alleviated with increasing fiber volume fraction and steel fiber aspect ratio $(28,29,30)$. In addition, specimens with corrugated and hooked-end fibers exhibit a better failure behavior than specimens with straight fibers, with multiply micro-cracks induced by mechanical interlocks of deformed steel fibers observed at the main cracks $(31,32,33)$.

The research program presented herein sets out to test a comprehensive number of HPC specimens with substantially varied parameters to expand the database of test results of the developed HPC. The subsequent objective is to study and quantify the material's postcracking characteristics of SFRC specimen, to improve or sustain abrasion-erosion \& cavitation problems associated with hydraulic structures.

\section{Experimental Program}

\subsection{Constitutive Materials}

Following concrete making materials have been used for the investigations on high performance concrete:

- Ordinary Portland Cement (OPC) 53 Grade satisfying to the specification of IS:12269-2013[34] [Table 1]

- $\quad$ Silica Fume (SF) satisfying to the specification of IS:15388-2003[35], [Table 1]

- Fine (Zone-II) \& Coarse aggregate $(20 \mathrm{~mm}$ downsize) satisfying to the specifications as per IS: 383-1970[36] [Table 2],

- Potable water

- Polycarboxylic Ether (PCE) based super plasticizer satisfying to the specification of IS:9103[37]

- Fibers: (i) Hooked end steel fibers of $0.55 \mathrm{~mm}$ diameter with an aspect Ratio of 63 satisfying to the specification of ASTM A 820[38]. The Material test certificate of tensile strength provided by manufacturer is $1468.99 \mathrm{~N} / \mathrm{mm} 2$ where minimum requirement is $345 \mathrm{~N} / \mathrm{mm} 2$ as per ASTM A 820 .

- (ii) Micro Polypropylene with properties as given in table 3 ware used. 
Table 1. Physical, Chemical and Strength Characteristics of Cement

\begin{tabular}{|c|c|c|}
\hline Characteristics & OPC -53 Grade & Silica Fume \\
\hline \multicolumn{3}{|c|}{ Physical Tests: } \\
\hline Fineness $\left(\mathrm{m}^{2} / \mathrm{kg}\right)$ & 320.00 & 22000 \\
\hline Soundness Autoclave (\%) & 00.05 & - \\
\hline Soundness Le Chatelier (mm) & 1.00 & - \\
\hline Setting Time Initial (min.) \& (max.) & $170.00 \& 220.00$ & - \\
\hline Specific gravity & 3.16 & 2.24 \\
\hline \multicolumn{3}{|c|}{ Chemical Tests: } \\
\hline Loss of Ignition (LOI) (\%) & 1.50 & 1.16 \\
\hline Silica $\left(\mathrm{SiO}_{2}\right)(\%)$ & 20.38 & 95.02 \\
\hline Iron Oxide $\left(\mathrm{Fe}_{2} \mathrm{O}_{3}\right)(\%)$ & 3.96 & 0.80 \\
\hline Aluminium Oxide $\left(\mathrm{Al}_{2} \mathrm{O}_{3}\right)$ & 4.95 & - \\
\hline Calcium Oxide $(\mathrm{CaO})(\%)$ & 60.73 & - \\
\hline Magnesium Oxide (MgO) (\%) & 4.78 & - \\
\hline Sulphate $\left(\mathrm{SO}_{3}\right)(\%)$ & 2.07 & - \\
\hline Alkalis (\%) $\quad \mathrm{Na}_{2} \mathrm{O} \& \mathrm{~K}_{2} \mathrm{O}$ & $0.57 \& 0.59$ & $0.73 \& 2.96$ \\
\hline Chloride $(\mathrm{Cl})(\%)$ & 0.04 & - \\
\hline IR $(\%)$ & 1.20 & - \\
\hline Moisture (\%) & - & 0.43 \\
\hline
\end{tabular}

Table 2. Properties of Aggregates

\begin{tabular}{ccccc}
\hline \multirow{2}{*}{ Property } & \multicolumn{2}{c}{ Granite } & Fine \\
Specific gravity & $20 \mathrm{~mm}$ & $10 \mathrm{~mm}$ & Aggregate \\
\hline Water absorption (\%) & 2.70 & 2.69 & 2.64 \\
& $40 \mathrm{~mm}$ & 0.32 & 0.35 & 0.72 \\
\hline & $20 \mathrm{~mm}$ & 95 & 100 & 100 \\
Sieve & $10 \mathrm{~mm}$ & 7 & 100 & 100 \\
Analysis & $4.75 \mathrm{~mm}$ & 0 & 95 & 95 \\
Cumulative Percentage & $2.36 \mathrm{~mm}$ & 0 & 19 & 87 \\
Passing (\%) & $1.18 \mathrm{~mm}$ & 0 & 0 & 68 \\
& $600 \mu$ & 0 & 0 & 38 \\
& $300 \mu$ & 0 & 0 & 10 \\
& $150 \mu$ & 0 & 0 & 2 \\
& Pan & 0 & 0 & 100 \\
\hline
\end{tabular}


Table 3. Properties of Polypropylene Fiber

\begin{tabular}{cc}
\hline Properties & Value \\
\hline Cut length (mm) & 12 \\
Effective diameter (micron) & $20-40$ \\
Specific gravity & $0.90-091$ \\
Melting point $\left({ }^{\circ} \mathrm{C}\right)$ & $160-165$ \\
Elongation $(\%)$ & $20-60$ \\
Alkaline stability & Very good \\
Young's modulus (MPa) & $>4000$ \\
\hline
\end{tabular}

\subsection{Mixture Proportion and Concrete Production}

The control concrete was designed \& optimized using $10 \%$ silica fume by weight of cement as per IS: 10262[39]. Mix proportions for fiber reinforced concrete were optimized using different percentages of steel and polypropylene fibers for the desired slump. Since hooked end steel fibers of $1,1.25 \& 1.5 \%$ by concrete volume \& micro-Polypropylene fiber dose of $1 \mathrm{~kg} / \mathrm{m} 3,2 \mathrm{~kg} / \mathrm{m} 3 \& 3 \mathrm{~kg} / \mathrm{m} 3$ was adopted for the study, some adjustments were done in the mix proportions to maintain the required slump. The dose of PCE based superplasticizer is adjusted and the ratio of fine to coarse aggregate is adjusted accordingly. Concrete mix proportions are shown in Table 4.

For conducting studies, the concrete mixes were prepared in pan type concrete mixer. Before use, the moulds were properly painted with mineral oil, casting was done in three different layers and each layer was compacted on vibration table to minimize air bubbles and voids. After 24 hours, the specimens were demoulded from their respective moulds. The laboratory conditions of temperature and relative humidity were monitored during the different ages at $27 \pm 20 \mathrm{C}$ and relative humidity $65 \%$ or more. The specimens were taken out from the tank and allowed for surface drying and then tested in saturated surface dried condition.

Table 4. Concrete Mix of Control and Fiber Reinforced Concrete

\begin{tabular}{|c|c|c|c|c|c|c|c|c|}
\hline $\begin{array}{c}\text { Type of } \\
\text { concrete }\end{array}$ & Designation & $\begin{array}{l}\text { Water } \\
\left(\mathrm{kg} / \mathrm{m}^{3}\right)\end{array}$ & $\begin{array}{c}\text { OPC } \\
\left(\mathrm{kg} / \mathrm{m}^{3}\right)\end{array}$ & $\begin{array}{c}\mathrm{SF} \\
\left(\mathrm{kg} / \mathrm{m}^{3}\right)\end{array}$ & $\begin{array}{l}\text { HRWRA } \\
\left(\mathrm{kg} / \mathrm{m}^{3}\right)\end{array}$ & $\begin{array}{c}\text { CA } \\
\left(\mathrm{kg} / \mathrm{m}^{3}\right)\end{array}$ & $\begin{array}{c}\text { FA } \\
\left(\mathrm{kg} / \mathrm{m}^{3}\right)\end{array}$ & $\begin{array}{c}\text { Fibers } \\
\left(\mathrm{kg} / \mathrm{m}^{3}\right)\end{array}$ \\
\hline Control & $\mathrm{CM}$ & 131.1 & 570 & 64 & 9.51 & 1093.0 & 625.0 & 0.00 \\
\hline $\begin{array}{c}\text { SFRC } \\
1 \%\end{array}$ & S1 & 131.1 & 570 & 64 & 10.30 & 1132.2 & 693.8 & 78.50 \\
\hline $\begin{array}{c}\text { SFRC } \\
1.25 \%\end{array}$ & S2 & 131.1 & 570 & 64 & 11.10 & 1126.6 & 693.8 & 98.13 \\
\hline $\begin{array}{l}\text { SFRC } \\
1.5 \%\end{array}$ & S3 & 131.1 & 570 & 64 & 11.89 & 1126.6 & 699.5 & 117.75 \\
\hline $\begin{array}{c}\text { PFRC } \\
1 \mathrm{~kg} / \mathrm{m} 3\end{array}$ & P1 & 131.1 & 570 & 64 & 9.51 & 1093.0 & 630.7 & 1.00 \\
\hline $\begin{array}{c}\text { PFRC } \\
2 \mathrm{~kg} / \mathrm{m} 3\end{array}$ & $\mathrm{P} 2$ & 131.1 & 570 & 64 & 10.30 & 1160.3 & 619.3 & 2.00 \\
\hline $\begin{array}{c}\text { PFRC } \\
3 \mathrm{~kg} / \mathrm{m} 3\end{array}$ & P3 & 131.1 & 570 & 64 & 11.10 & 1160.3 & 619.3 & 3.00 \\
\hline
\end{tabular}


${ }^{*} \mathrm{OPC}=$ Ordinary Portland Cement, $\mathrm{SF}=$ Silica fume, CA=Coarse Aggregate, FA=fine Aggregate, HRWRA=High Range Water Reducing Agent/Admixtures, SFRC=Steel fiber reinforced concrete \& PFRC= Polypropylene fiber reinforced concrete

The laboratory conditions were maintained as per Indian Standard during casting, placing \& testing of concrete specimen i.e. $27 \pm 2 \mathrm{oC}$ and $65 \pm 5 \mathrm{RH}$. The slump, measured as per IS: 1199 [40] of control concrete was $150 \mathrm{~mm}$. It was observed that the slump value decreases with the introduction of fibers into the mixture which affects the workability of the concrete. To maintain the required workability slump of 130-150 mm, dose of PCE based HRWRA is adjusted and more fines are added to mix.

The air content of mixes was measured as per ASTM C 231 [41] (pressure method) and it was found that it increases with introduction of steel fibers by 30 to $50 \%$. The wet density of CM and PFRC was around $2542 \mathrm{~kg} / \mathrm{m} 3$ while slightly more density was observed for SFRC mix i.e., $2560 \mathrm{~kg} / \mathrm{m} 3$. The setting times (both initial and final) of all mixes were determined as per IS:8142 [42] and were found to be fairly similar i.e., 7.5 hours \& 9.2 hours respectively.

\section{Test Setup}

\subsection{Mechanical Parameters: Compressive Strength, Flexural Strength and Splitting Tensile Strength}

The compressive and flexural strength tests were carried out at 3, 7 and 28 day's age on cubes $(150 \mathrm{~mm})$ and beams $(100 \times 100 \times 500 \mathrm{~mm})$ respectively. The test procedure followed during the tests was in conformity with IS: 516 [43] for compressive strength test and ASTM C1609 [44] for flexure strength test. Splitting tensile strength test was carried out at 3, 7 and 28 day's age on cylinder specimen ( $150 \mathrm{~mm}$ diameter $\& 300 \mathrm{~mm}$ length) as per in IS: 5816 [45]. Drying Shrinkage test was carried out on prism $(75 \times 75 \times 300 \mathrm{~mm})$ at 28 day's age as per IS: 1199 [40].

\subsection{Flexure Toughness Test}

The flexure test apparatus consisting of a three-point bending with pin and roller type supports was used. The specimen size was $100 \times 100 \times 500 \mathrm{~mm}$ with clear span of 400 $\mathrm{mm}$. Test was carried out as per the provisions of ASTM C 1609 [27]. Test was carried out in displacement control mode in a servo controlled closed-loop system with a bending yoke where Linear Variable Displacement Transducers (LVDT) were mounted on the sides of the yoke around the specimen. These LVDT's were connected to display unit to measure the net deflection at the center of the beam. Experimental setup is shown in Fig. 1. The test facility is specifically developed to study the post cracking behavior of fiber reinforced concrete and measure the flexural toughness of the test specimen. 


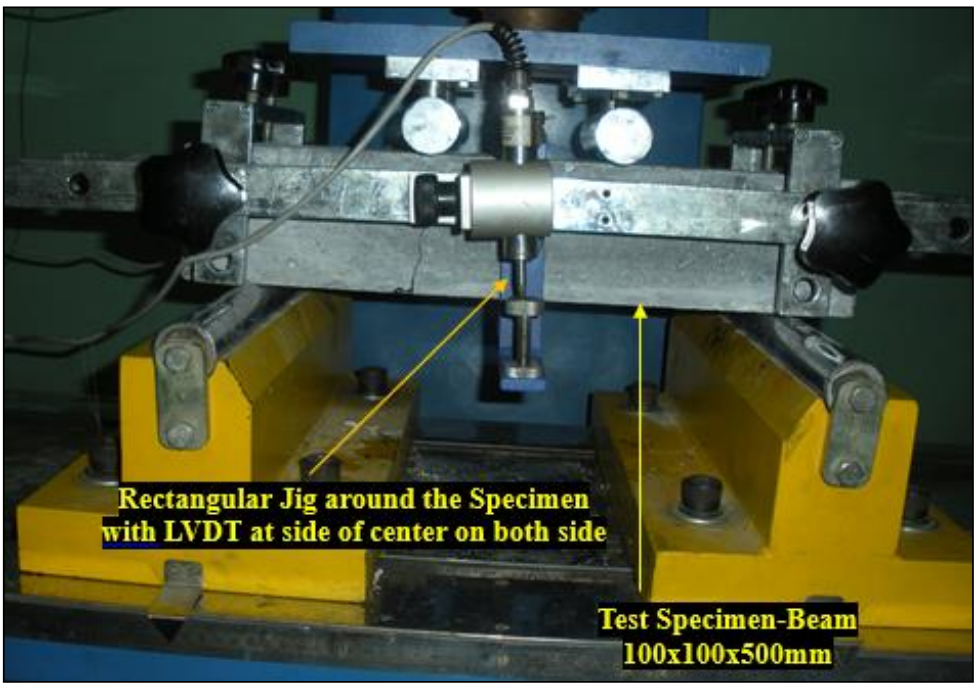

Fig. 1 Experimental flexure toughness test setup as per ASTM C 1609[27].

\subsection{Abrasion Resistance Test (Under Water Method) as per ASTM C1138}

The abrasion test (under water method) was carried out at 28 days on a concrete specimen with dimensions of $300 \mathrm{~mm}$ diameter and $100 \mathrm{~mm}$ thickness as per the procedure given in ASTM C-1138. The test set up and specimen of abrasion test (under water method) is shown in Fig. 2.
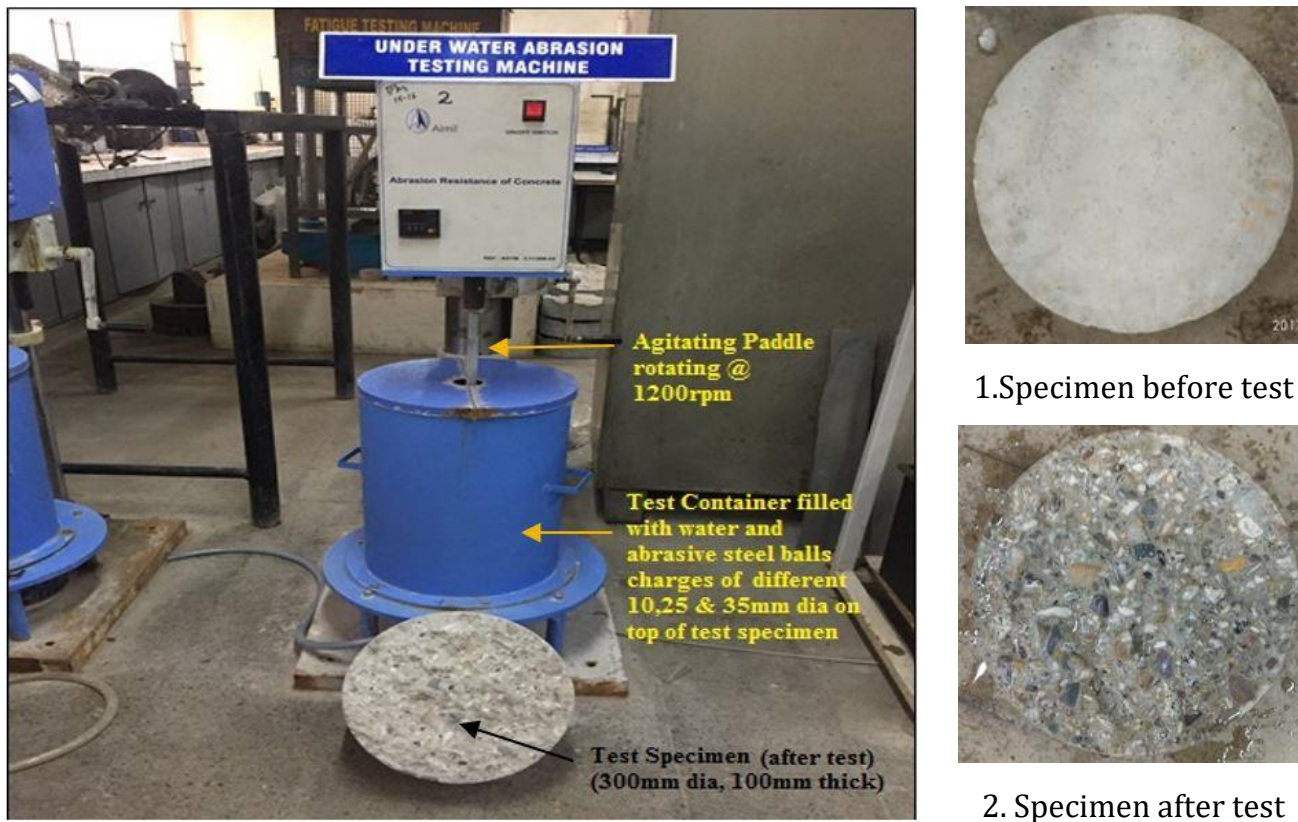

1.Specimen before test

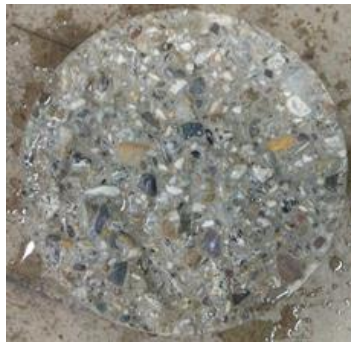

2. Specimen after test

Fig. 2 Abrasion test (Under water method) setup as per ASTM C 1138

The initial mass of the concrete specimen (Diameter $300 \pm 2 \mathrm{~mm} \&$ Height $100 \pm 13 \mathrm{~mm}$ ) were recorded in air \& in water, then the specimen was kept in test container with surface 
to be tested facing up on the seating blocks. The agitation paddle was placed such that the bottom of paddle was $38 \pm 5 \mathrm{~mm}$ above the surface of specimen. The abrasive charges (Steel balls) were placed on the surface of specimen and water was added upto $165 \pm 5 \mathrm{~mm}$ above surface of specimen. Then the agitating paddle was rotated at the rate of $1200 \pm 100 \mathrm{rpm}$. The specimen was removed from test container at the end of every 12-hours of operation and the abraded material was flushed off \& surface of specimen was dried off. The mass of specimen was recorded again in air \& water. The test was repeated for six times of 12 hours periods for a total of 72 hours and final mass loss was recorded.

\subsection{Abrasion Resistance Test (Revolving Disk Method) as per ASTM C 779}

The abrasion test was carried out at accelerated 28 days on a concrete slab of size $300 \times$ $300 \mathrm{~mm}$ with $100 \mathrm{~mm}$ thickness as per the procedure given in ASTM C-779 (46). The test set up and specimen of abrasion test (revolving disk method) is shown in Fig. 3.
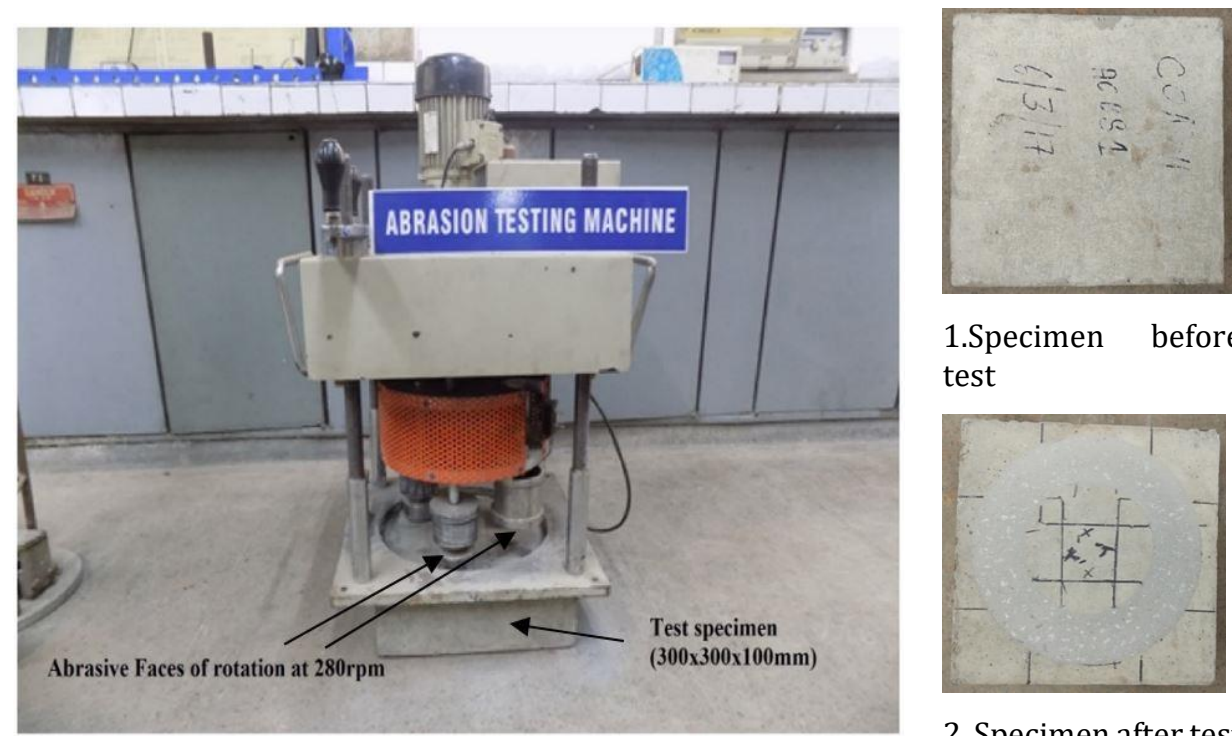

1.Specimen before test

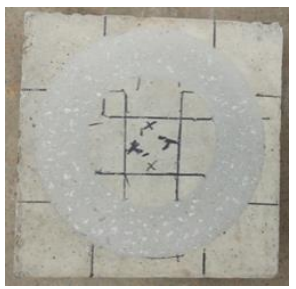

2. Specimen after test

Fig. 3 Abrasion Test (Revolving Disk Method) Setup as per ASTM C 779

\subsection{Water and Air Permeability}

Water permeability test was carried out at the age of 28 day's age on concrete cylinder (150 mm diameter \& $150 \mathrm{~mm}$ height) as per DIN-1048[47] and Air permeability test at 28 days was carried out on slabs $(300 \times 300 \times 100 \mathrm{~mm})$ using Torrent Permeability tester.

\section{Result and Discussion}

\subsection{Mechanical Parameters: Compressive Strength, Flexural Strength $\&$ Splitting Tensile Strength}

\subsubsection{Compressive Strength}

The result of compressive strength at $3,7 \& 28$ days of control \& fiber reinforced concrete is shown in Fig. 4. Test result indicates that the compressive strength of control concrete and micro polypropylene fiber reinforced concrete specimens are fairly similar. There is a substantial increase in the compressive strength of steel fiber reinforced concrete as 
compared to control concrete. The compressive strength of the steel fiber-reinforced concrete is maximum at $1.25 \& 1.5 \%$ steel fibers with 12 \& $14 \%$ increment respectively.

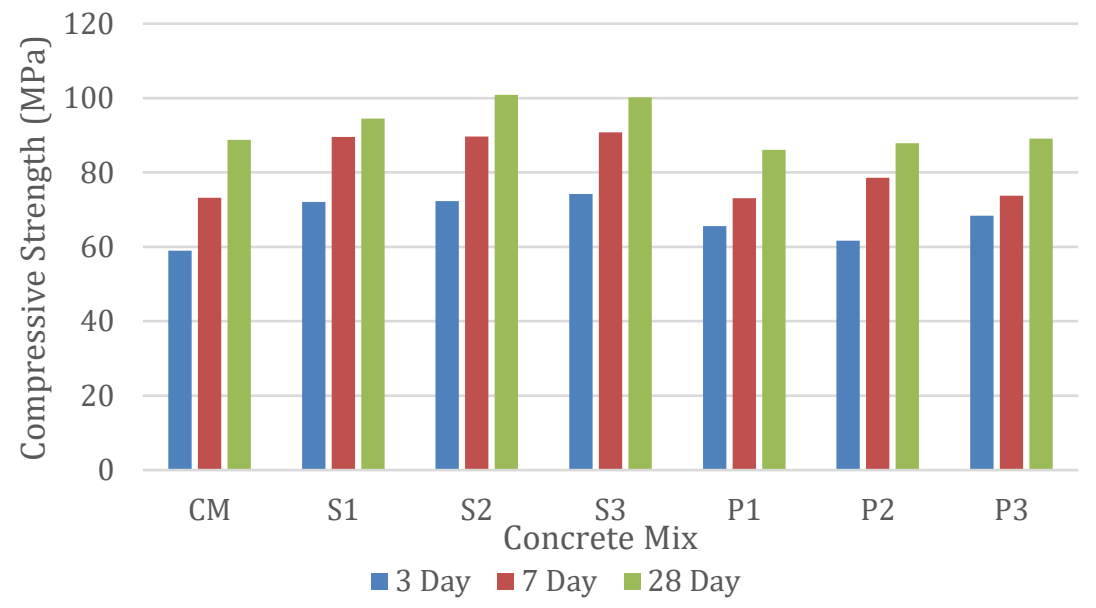

Fig. 4 Compressive Strength at 3, 7 and 28 Days

The significant increase in compressive strength of the concrete with steel fibers is a result of increased concrete integrity wherein steel fibers randomly distributed in concrete matrix binds the composites together and restricts the disintegration upon loading to peak stress.

\subsubsection{Flexural Strength}

Flexural strength at 3,7 \& 28 days of the mixes (CM, SFRC \& PFRC) covered in the study is shown in Fig. 5. From test results it is observed that there is an increase in the flexural strength with the introduction of fibers into the mix. For micro polypropylene fibers reinforced concrete the increments are in the range of $7 \%$ to $18 \%$ and for steel fiber reinforced concrete it varies from $20 \%$ to $42 \%$.

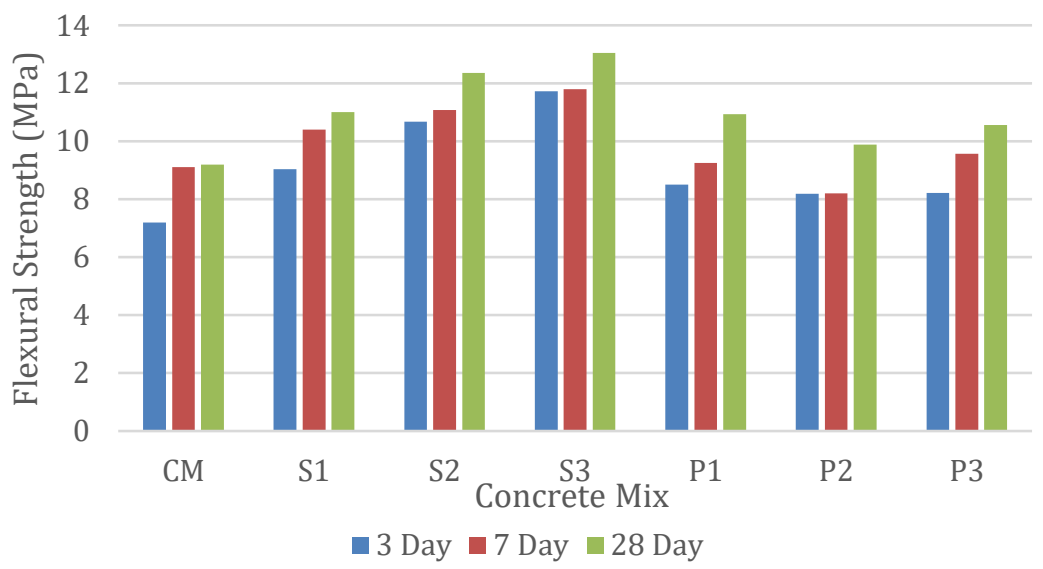

Fig. 5 Flexural Strength at 3, 7 and 28 Days 
The increase in the flexural strength of the concrete can be attributed to the bridging action of fibers which acts as a tensile reinforcement and subsequently increases the flexural capacity of the beam. Fibers addresses the tensile strength by two mechanisms wherein first mechanism it reduces the crack propagation by bridging action while in second mechanism it delays the crack initiation by contribution to the loading before initiation of cracks at surface.

\subsubsection{Splitting Tensile Strength}

Splitting tensile strength at $3,7 \& 28$ days of control \& fiber reinforced concrete is shown in Fig. 6. Test results indicate that the tensile strength of control and micro polypropylene fiber reinforced concrete specimens are almost similar. In case of SFRC, there is a substantial increase in the tensile strength compared to control by about $40 \%$ to $75 \%$. Uniformly distributed Fibers acts as a tensile reinforcement due which this significant increase in splitting tensile strength can be seen. A part of initial load is taken by the steel fibers and full load is transferred to the concrete once the fibers fails by pull out or break out of the fibers from the concrete matrix.

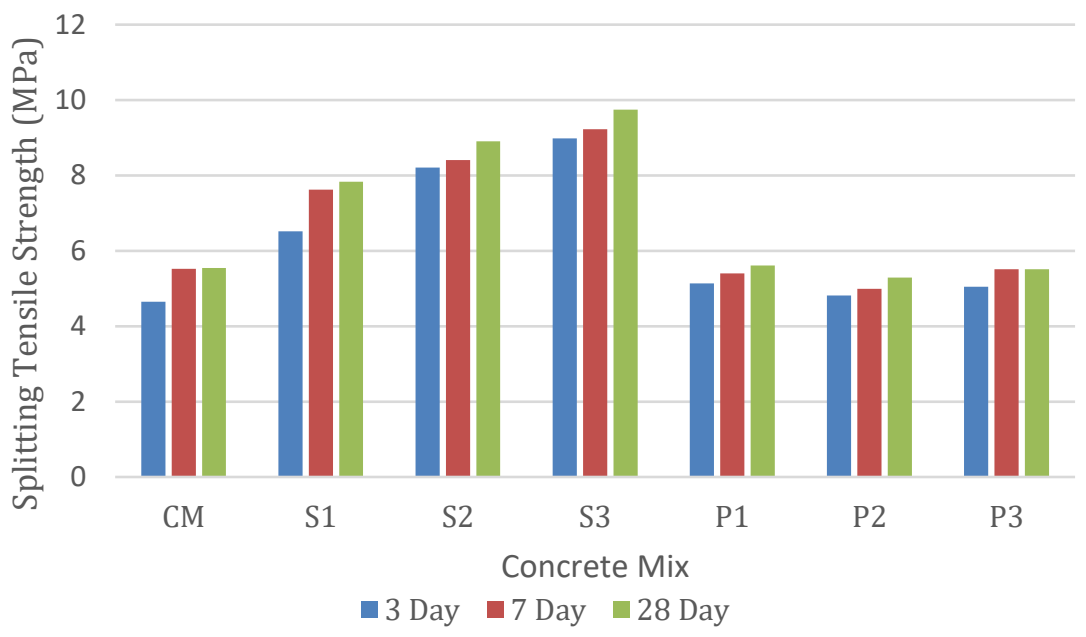

Fig. 6 Splitting Tensile Strength at 3, 7 and 28 Days

\subsubsection{Load - Deflection Behavior}

Based on test results of SFRC segments (S1, S2 \& S3) as shown in Fig. 7 and Fig. 8, addition of steel fibers into the mix result in ductile response in load deflection curve. The loaddeflection response of fibre reinforced concrete generally starts by an initial portion that is linearly elastic up to a certain load and then deviates from its linearity. This is often identified as the onset of first cracking in the matrix. If the cement matrix is not reinforced with fibers, first cracking is followed by a sudden drop in the load-deflection curve, and failure occurs which is observed in case of control concrete. The addition of steel fibers mostly influences the response of the concrete mixture after the onset of initial cracks by the bridging action. These fibers reduce the crack propagation by addressing the tensile loads and acts as a tensile reinforcement which results in the ductile failure while the control concrete being brittle in nature undergoes sudden failure. 


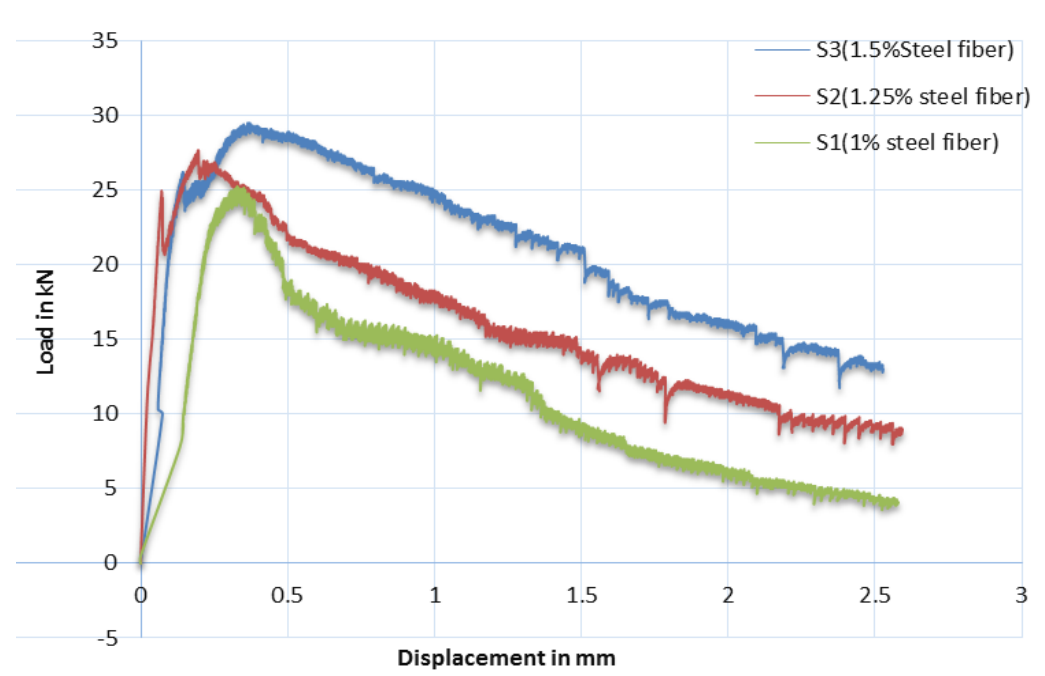

Fig. 7 Load - Displacement Curves of SFRC (S1, S2 \& S3) Specimen at 7 Day

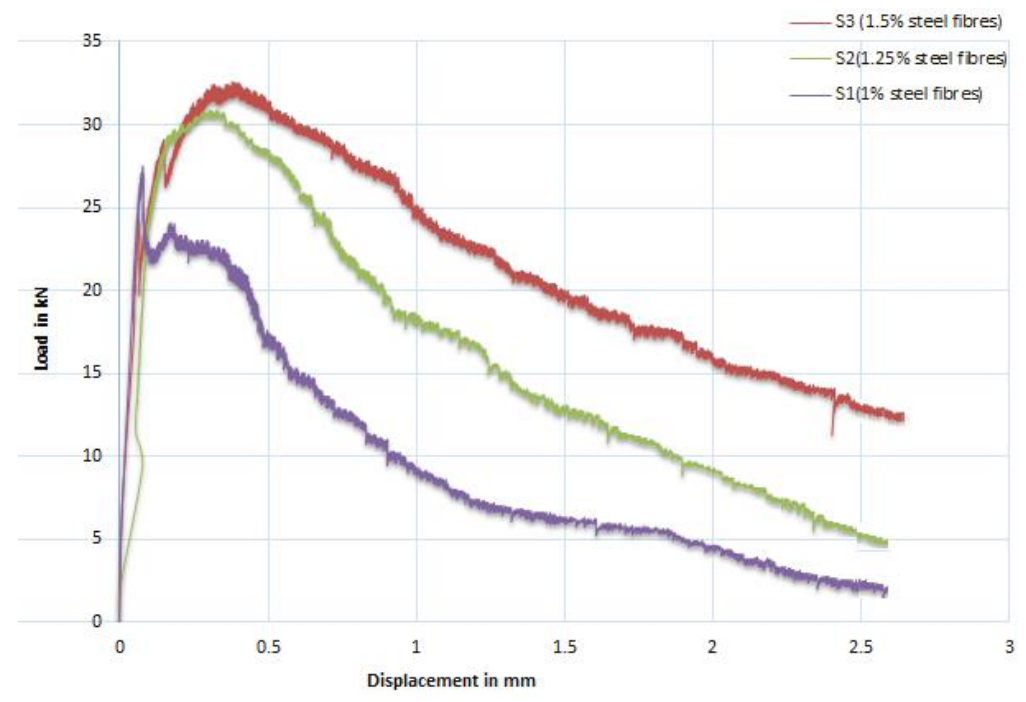

Fig. 8 Load - Displacement Curves of SFRC (S1, S2 \& S3) Specimen at 28 Day

\subsubsection{Mode of Failure}

Steel fibers in concrete allows the bridging of cracks, which aids in increasing the ductility of the concrete after the post cracking stage. The crack behaviour of S1, S2 \& S3 also shows different pattern. S1 shows single crack whereas S2 \& S3 shows multiples cracks, this maybe because, if the fibre content in the mix is more, it is possible that the load- bearing capacity of the fibers is greater than the load on the composite at the first crack. Additional loading will result in additional cracks, until the matrix is divided into a number of segments separated by cracks. The cracking may stop when the stress transferred to the matrix no longer exceeds the cracking load. For all practical purposes, the load-deflection response of fibre reinforced cement composites can be classified as either "strain- 
softening" or "strain-hardening. As per Naaman [31], High performance fiber reinforced cement composites are a class of FRC composites characterized by a strain hardening behavior in tension after first cracking, accompanied by multiple cracking up to relatively high strain levels.

From load-deflection curve of SFRC at 28 days S1 shows strain softening, the load carrying capacity decreases gradually after the onset of first crack load of $27.5 \mathrm{kN}$, whereas S2 \& S3 show strain hardening i.e. even after the onset of first cracks load at $28.3 \mathrm{kN} \& 29.4 \mathrm{kN}$ the segment load carrying capacity increases till it reaches ultimate crack load at $30.8 \mathrm{kN} \&$ $32.3 \mathrm{kN}$ respectively which is tabulated in Table 5.

The area under load- deflection curve from 0 to $\mathrm{L} / 150$ (here $\mathrm{L}=400 \mathrm{~mm}$ ) is the flexural toughness which is the apparent amount of energy absorbed by the specimen. The toughness of Steel Fibre Reinforced Concrete analyzed as per ASTM C 1609[25] from the load - deflection curve at 28days strength are 27, 43 \& 59 Joules respectively for S1, S2 \& S3 mix.

Table 5. Summary of Parameters Obtained from Load-Deflection Curve Of SFRC Specimen as per ASTM C $1609^{[28]}$ at 28 Days

\begin{tabular}{cccc}
\hline Parameters & \multicolumn{3}{c}{ HS-SFRC } \\
\cline { 2 - 4 } & $\mathrm{S} 1$ & $\mathrm{~S} 2$ & $\mathrm{~S} 3$ \\
\hline $\begin{array}{c}\text { Fist peak Load in kN } \\
\text { Peak load in kN }\end{array}$ & 27.5 & 28.3 & 29.4 \\
$\begin{array}{c}\text { Fist Peak Strength in MPa } \\
\text { Peak Strength in MPa }\end{array}$ & - & 30.8 & 32.3 \\
$\begin{array}{c}\mathrm{kN} \\
\text { Residual load at net deflection of L/600 in }\end{array}$ & 11.0 & 11.32 & 11.76 \\
$\begin{array}{c}\text { Residual strength at net deflection of L/600 } \\
\text { in MPa }\end{array}$ & 13.8 & 24.7 & 29.5 \\
$\begin{array}{c}\text { Residual load at net deflection of L/150 in } \\
\text { kN }\end{array}$ & 3.52 & 9.88 & 11.80 \\
$\begin{array}{c}\text { Residual strength at net deflection of L/150 } \\
\text { in MPa }\end{array}$ & 1.28 & 2.80 & 12.6 \\
$\begin{array}{c}\text { Area Under the load vs net deflection curve } \\
\text { 0 to L/150 in Joules }\end{array}$ & 27.0 & 43 & 5.04 \\
\hline
\end{tabular}

Strength is calculated as $\mathrm{PL} / \mathrm{bd} 2$, where $\mathrm{P}=$ load in $\mathrm{kN}$ at corresponding displacement. $\mathrm{L}=$ length of specimen in $\mathrm{mm}, \mathrm{b}=$ width of specimen in $\mathrm{mm}$ and $\mathrm{d}=$ depth of specimen in $\mathrm{mm}$.

\subsection{Durability Parameters: Drying Shrinkage, Abrasion, Water and Air Permeability}

\subsubsection{Drying Shrinkage}

The result of drying shrinkage of control \& fiber reinforced concrete is shown in Fig. 9. From the figure, a reduction in drying shrinkage can be observed of $20 \%$ to $37 \%$ in PFRC as compared to the control while in case of SFRC reduction of 8 to $29 \%$ is observed. Fibers incorporated in concrete are known to control cracking arising from drying and/or plastic shrinkage behaviour in the cementitious matrix. The mitigation of drying shrinkage aids the concrete aesthetically and also by controlling and preventing shrinkage cracks the durability of concrete can be enhanced. 


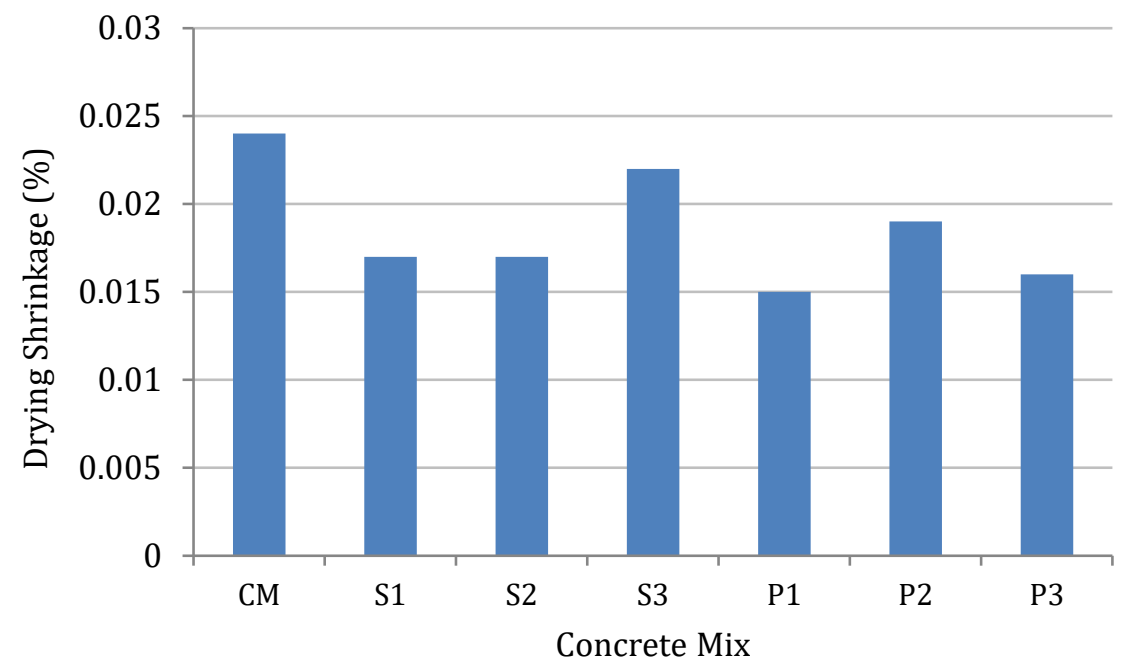

Fig. 9 Drying Shrinkage at 28 Day

\subsubsection{Abrasion Resistance Test (Under Water Method) as per ASTM C1138}

From the test result (Fig. 10), the 28 days age cumulative abrasion volume loss in $\mathrm{m} 3 \mathrm{for}$ control mix is $110 \times 10^{-6} \mathrm{~m} 3$ and for Steel fiber reinforced concrete mix of $1 \%$ to $1.5 \%$ of steel fibers by volume varies from $102 \times 10^{-6}$ to $120 \times 10^{-6} \mathrm{~m}^{3}$ while for concrete mix with polypropylene fibers volume loss varies from $111 \times 10^{-6}$ to $109 \times 10^{-6} \mathrm{~m} 3$.

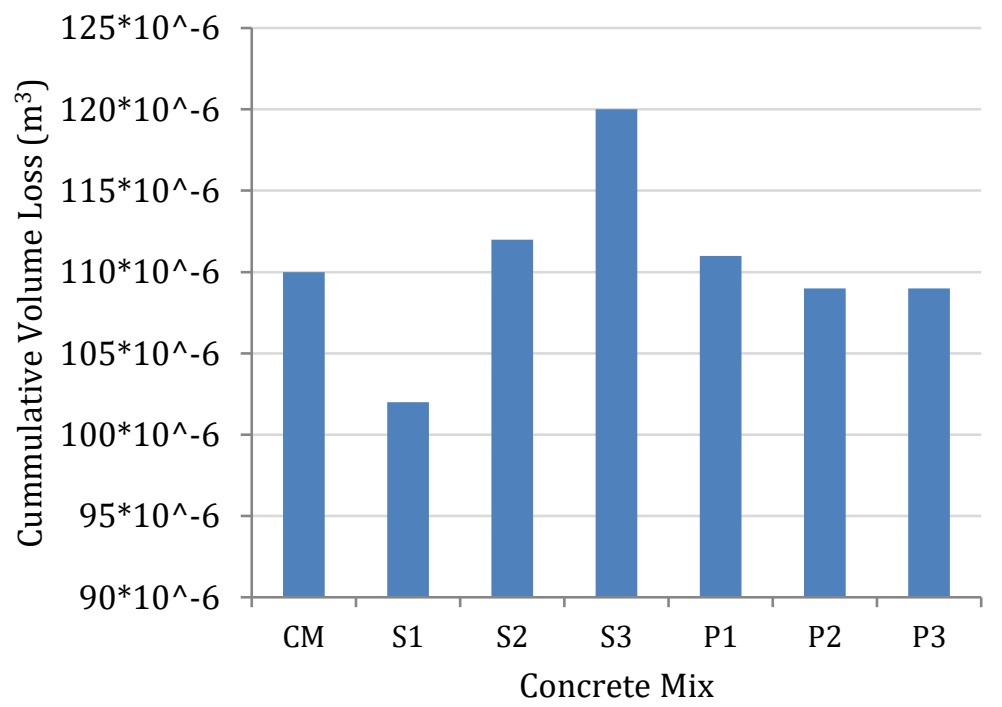

Fig. 10 Abrasion Resistance Test (Under Water Method)

This test result shows varying abrasion loss when steel fibers are introduced into the mix, more abrasion volume loss is observed as compared to control mix. This is primarily due 
to abrasion of mortar part of concrete as in SFRC, adjustments were made in the mix proportions to accommodate steel fibers which reduces coarse aggregate content and increases the paste content. It was observed that the coarse aggregates in concrete were not getting abraded in this test.

\subsubsection{Abrasion Resistance Test (Revolving Disk Method) as per ASTM C 779}

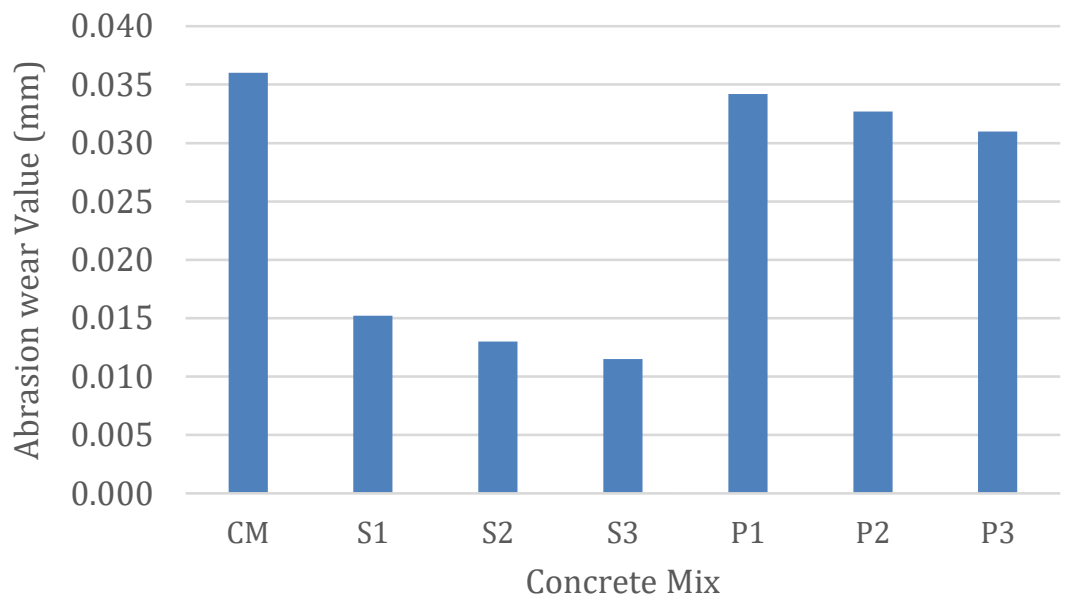

Fig. 11 Abrasion Wear Value at 28 Day

From Fig. 11, the inclusion of fibers produced an improvement in the abrasion resistance of the concrete. In this study, it was found that the most significant improvement was achieved with the optimum inclusion of steel fibers at $1.5 \%$ by volume, it can be also seen that abrasion wear decreases with increase in fibers percentage. The reduction in abrasion wear value of SFRC to that of control concrete is 58 to $68 \%$ \& $5 \%$ to $13.89 \%$ for PFRC.

Considering the test results of both methods of abrasion resistance tests, SFRC can be a viable solution for repairs and construction specific elements critical to erosive or abrasive action in hydraulic structures. By increasing the integrity of the concrete, steel fibers hold the composites together and reduces the disintegration of aggregates and thus addresses the problem of cavitation and erosion of concrete constituents.

\subsubsection{Water Permeability}

Concrete Samples were cast and tested for water permeability after 28 days of water curing. Results of the test from Fig. 12 indicates significant decrease in the permeability of concrete with the addition of steel fibers. Test result shows that in SFRC specimen water penetration is almost negligible as the reduction of water penetration percentages vary from $61 \%$ to $99 \%$. This is most likely due to the stitching and multiple cracking effect of the steel fibers. Steel fibers seems more effective as compared to polypropylene fibers as per the experimental results. 


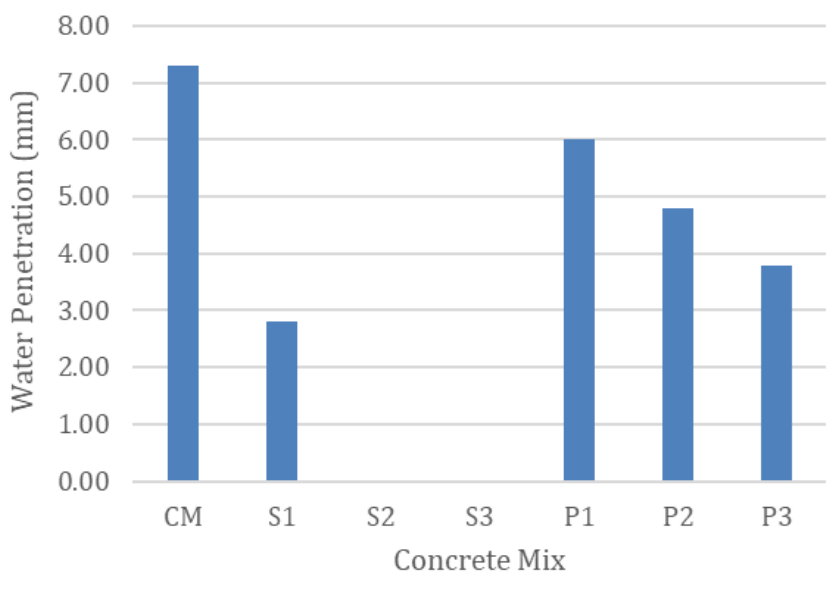

Fig. 12 Water Penetration at 28 Day

\subsubsection{Air Permeability}

From Fig. 13 it is observed that the air permeability coefficient (kT-16m2) value of SFRC specimens are less than that of control concrete by $80 \%$ to $91 \%$ and while in case of PFRC specimens values are 14 to $76 \%$ less than the control. The result indicates the quality of concrete as good. The permeability coefficient decreases with increase in steel fibers percentage by volume in the mix.

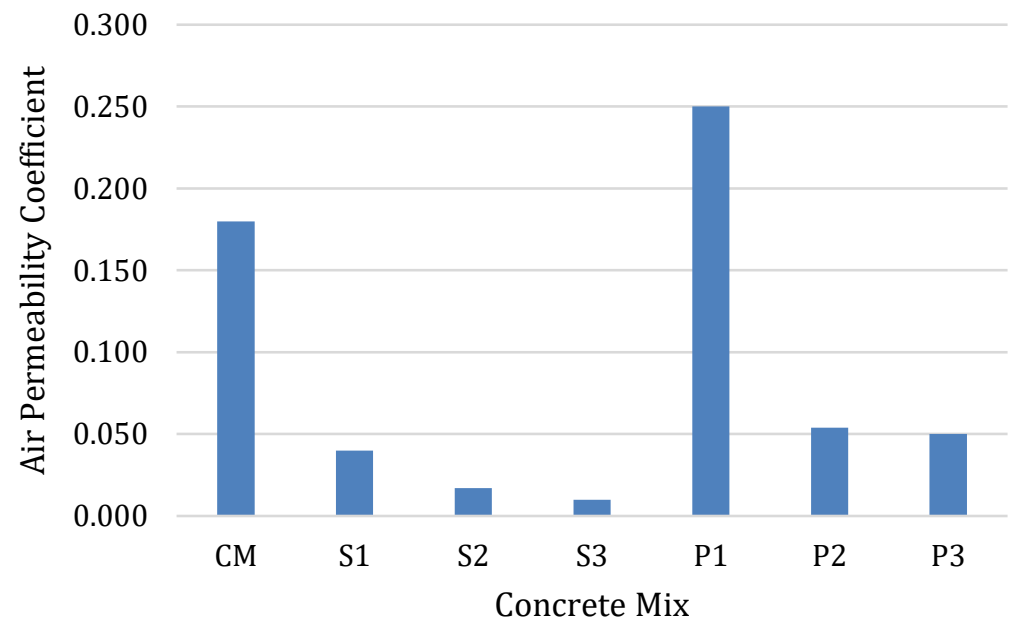

Fig. 13 Air Permeability Coefficient at 28 Day

The reduction in air and water permeability of the SFRC reduces the ingress of chlorides, sulphates, etc. from the constant contact of water. Further, this reduction in permeability can be attributed to the reduced number and depth/width of the micro cracks on the surface of concrete due to incorporation of steel fibers. Bridging action of steel fibers plays an important role in increasing the overall integrity of the concrete. 


\section{Conclusion}

The addition of different fibers affects the different properties and steel fibers have been proven more efficient in addressing the abrasion and erosion in the hydraulic structures. Following conclusions can be drawn with respect to the properties studied:

- $\quad$ High Strength Steel Fiber Reinforced Concrete incorporating 1, 1.25 \& 1.5\% steel fibers have improved mechanical \& durability properties substantially as compared to Control \& Polypropylene Fiber Reinforced Concrete of same water to binder ratio. Addition of polypropylene fibers will not be a viable solution wherein abrasive and repetitive loading is applicable.

- Among the three HS-SFRC mix selected for evaluation, the mix with $1.5 \%$ steel fibers shows maximum strain hardening behavior in the load deflection curve indicating that the specimen can absorb more energy, comparatively.

- The Toughness or energy absorption \& residual strength of HS-SFRC with $1.5 \%$ steel fiber content is highest compared to HS-SFRC with $1 \%$ \& $1.25 \%$ steel fibers. Therefore, HS-SFRC with $1.5 \%$ steel fiber can sustain higher impact at higher velocities and will result in lesser deterioration of concrete by flowing water containing large debris, boulders, etc.

- $\quad$ This test result for abrasion resistance test (Under water method) shows varying abrasion loss when steel fibers are introduced into the mix, more abrasion volume loss is observed as compared to control mix. The test results for abrasion resistance test (Revolving Disk method) shows the reduction in abrasion wear value of SFRC compared to that of control concrete in the range of 58 to $68 \%$. Therefore, considering both the results of both tests use of steel fibers will be more efficient and effective against the abrasive action water in hydraulic structures.

- Air and water permeability has been substantially reduced upon addition of steel fibers which will increase the resistance to ingress of chlorides, sulphates and other ions and will enhance the durability of the concrete.

- With the overall improvement in engineering characteristics as reported in this paper, the optimized mix incorporating $1.5 \%$ steel fibers is found suitable for application in spillways where cavitation due to impact is of major concern $\& 1.25 \%$ to $1.5 \%$ for abrasion-erosion in glacis.

\section{Acknowledgement}

The Research work presented in this paper was sponsored by NHPC Limited (LoA No: NH/R\&D/MOU/366/174, dated 5th December 2013). The authors are thankful to Mr. S P S Kundla and Mrs. Renu Badrasen from NHPC Limited, India for their technical support in this research work.

\section{References}

[1] Tony C, Liu James E, Mc Donald. Abrasion-erosion resistance of fibre reinforced concrete, Structural laboratory U S Army Engineer Waterways, 1981.

[2] Terrence CH. Abrasion-erosion Evaluation of concrete Mixtures for stilling basin Repairs Kinzua Dam, Pennsylvania, Structural laboratory U S Army Engineer Waterways, 1983.

[3] Papenfus N. Applying concrete technology to abrasion Resistance. Proceedings of 7th International Conference on Concrete Block Paving, Sun City, South Africa, October 2003. 
[4] Galvao JCA, Portella KF, Kormann ACM. Abrasive effects observed in concrete hydraulic surfaces of dams and application of repair materials, Federal Technological University of Parana, Brazil, March, 2012.

[5] Wu CH, Yen T, Liu YW, Hsu TH. The Abrasion erosion resistance of Concrete Containing Blast Furnace Slag, Taiwan Power Company Report, 1994.

[6] Kryzanowski A, Mikos M, Sustersistic J, Plannic I. Abrasion resistance of concrete in hydraulic structures, ACI Materials Journal, 2009; 106:4, 349-356. https://doi.org/10.14359/56655

[7] ACI Committee 546.R-2004. Concrete Repair Guide, 2004.

[8] ACI Committee 210R-1993. Erosion of Concrete in Hydraulic Structures, 1993.

[9] ACI Committee 544.4R-1988. Design consideration for steel Fibre Reinforced Concrete,

[10] Lin WT,Cheng An. Abrasion resistance of cement-based composites, 2012. https://doi.org/10.5772/34798

[11] Hu XG, Momber AW, Yin YG. Hydro-abrasive erosion of steel-fibre reinforced hydraulic concrete, Institute of Tribology, Hefei University of Technology, Hefei, China, WOMA Apparatebau GmbH Duisburg, Germany, 2002. https://doi.org/10.1016/S0043-1648(02)00215-6

[12] Stig O. Lack of practicable Standards \& test methods restrict the development of Steel fibre Shotcrete, Steel fibre concrete US-Sweden joint seminar (NSF-STU) Stockholm, Sweden, June, 1985.

[13] ACI Committee 544.1R-1996. State-of-the-Art Report on Fiber Reinforced Concrete.

[14] Shah SP, Jeng YS. Fracture Resistance of Steel Fiber Reinforced Concrete, Steel fibre concrete US-Sweden joint seminar (NSF-STU) Stockholm, Sweden, June, 1985.

[15] Gopalaratnam VS, Shah SP. Strength, Deformation \& Fracture Toughness of fiber cement composite at different rates of flexural loading" Steel fibre concrete US-Sweden joint seminar (NSF-STU) Stockholm, Sweden, June, 1985.

[16] Khayat KH, Kassimi F, Ghoddousi P. Mixture design and testing of fiber-reinforced Self Consolidating concrete. ACI materials journals, 2014, 111(2), 143-151. https://doi.org/10.14359/51686722

[17] Naaman AE. Engineered Steel fibers with optimal properties for reinforcement of cement Composite-Advanced concrete technology, Japan Concrete Institute, Japan, November, 2003, 1 (3), 241-252. https://doi.org/10.3151/jact.1.241

[18] Sharma S, Kumar S, Daniel YN, Arora VV. Improvement in abrasion resistance \& other engineering characteristics of Concrete using Low Grade Coarse Aggregates Using Silica Fume \& Steel Fiber, Proceedings of the NCB seminar on Durability and service life design of Concrete Structure, New Delhi, India, April, 2017.

[19] Sharma S, Arora V, Kumar S, Daniel Y N, Sharma A. Durability study of high strength steel fiber reinforced concrete, ACI material Journal, 2018,115 (2), 219-225. https://doi.org/10.14359/51701122

[20] Salimbahrami SR, Shakeri R. Experimental investigation and comparative machinelearning prediction of compressive strength of recycled aggregate concrete. Soft Computing, January, 2021. https://doi.org/10.1007/s00500-021-05571-1

[21] Swamy, RN. High-strength concrete-material properties and structural behavior, Spec. Publications, 1985, 87, 119-146.

[22] Aslani F, Nejadi S, Samali B. Long-term flexural cracking control of reinforced selfcompacting concrete one way slabs with and without fibres, Comput. Concrete, (2014a), 14(4), 419-443. https://doi.org/10.12989/cac.2014.14.4.419

[23] Aslani F, Nejadi S, Samali B. Short term bond shear stress and cracking control of reinforced self-compacting concrete one way slabs under flexural loading, (2014b), Comput. Concrete, 13(6), 709-737. https://doi.org/10.12989/cac.2014.13.6.709

[24] Kandekar SB, Talikoti R S. Torsional behaviour of reinforced concrete beams retrofitted with aramid fiber, Advances in concrete construction, 2020, 9 (1), 1-7. https://doi.org/10.3390/fib7020011 
[25] Raj SD, Ganesan N, Abraham, R. Role of fibers on the performance of geopolymer concrete exterior beam column joints, Advances in concrete construction, 2020, 115123.

[26] Mansouri I, Shahheidari F S, Hashemi, SMA, Farzampour, A. Investigation of steel fiber effects on concrete abrasion resistance, Adv. Concrete Constr., 2020, 9(4), 367-374.

[26] Li B, Chi Y, Xu L, Shi Y, Li, C. Experimental investigation on the flexural behavior of steel-polypropylene hybrid fiber reinforced concrete, Constr. Build. Mater., 2018, 191, 80-94. https://doi.org/10.1016/j.conbuildmat.2018.09.202

[28] Sharma R, Bansal PP. Efficacy of supplementary cementitious material and hybrid fiber to develop the ultra-high performance hybrid fiber reinforced concrete, Adv. Concrete Constr., 2019, 8(1), 21-31.

[29] Ojha PN, Singh B, Singh A, Patel V, Arora VV. Experimental study on creep and shrinkage behavior of high strength concrete for application in high rise buildings, Indian Concrete Journal, 2021; 95 (2), 30-42.

[30] Arora V V, Singh B, Jain S. Effect of indigenous aggregate type on mechanical properties of high strength concrete, Indian Concrete Journal, 2017, 91 (1), 34-44.

[31] Arora VV, Singh B, Jain S. Experimental studies on short term mechanical properties of high strength concrete. Indian Concrete Journal, 2016, 90 (10), 65-75.

[32] Singh B, Arora VV, Patel V. Study on stress strain characteristics of high strength concrete". Indian Concrete Journal, 2018, 92 (6), 37-43.

[33] Arora VV, Singh B, Patel V, Daniel YN, Mohapatra BN. Stress-Strain Behaviour and Performance Evaluation of High Strength Steel Fibre Reinforced Concrete, 2019, 93 (12).

[34] IS: 12269-1987. Specification for 53Grade Ordinary Portland Cement, Bureau of Indian Standard, New Delhi, India.

[35] IS: 15388-2003. Silica Fume Specification, Bureau of Indian Standard, New Delhi, India.

[36] IS: 383-1970. Specifications for coarse and fine aggregates from natural sources for concrete, Bureau of Indian Standards, New Delhi, India.

[37] IS: 9103-1999. Concrete admixture specification", Bureau of Indian Standards, New Delhi, India.

[38] ASTM A-820-2016. Standard specification for steel fibre reinforced concrete, Annual Books of ASTM Standards.

[39] IS: 10262-1982. Recommended guidelines for Concrete Mix Design, Bureau of Indian Standards, New Delhi, India .

[40] IS: 1199-1959, Methods of Sampling and Analysis of Concrete, Bureau of Indian Standards, New Delhi, India.

[41] ASTM C 231-2010. Standard Test Method for Air Content of Freshly Mixed Concrete by the Pressure Method, Annual Books of ASTM Standards.

[42] IS: 8142-1976. Method of Test for Determining Setting Time of Concrete by Penetration Resistance, Bureau of Indian Standards, New Delhi, India.

[43] IS: 516-1959. Methods of Tests for Strength of Concrete, Bureau of Indian Standards, New Delhi, India.

[44] ASTM C-1609-2012. Flexural Performance of Fiber-Reinforced Concrete (Using Beam with Third Point Loading), Annual Book of ASTM Standards.

[45] IS: 5816-1999. Splitting Tensile Strength of Concrete Method of Test, Bureau of Indian Standards, New Delhi, India.

[46] ASTM C 779-2019. Standard Test Method for Abrasion Resistance of Horizontal Concrete Surfaces, Annual Book of ASTM Standards.

[47] DIN 1048 (part5). Testing of Hardened Concrete (Specimens Prepared in the Mould), June, 1991. 